\title{
Efficient Alternate Crops and Cropping Systems for Sugarcane
}

\author{
S. N. O. Sadashivanagowda ${ }^{1 *}$, S. C. Alagundagi ${ }^{1}$ and B. T. Nadagouda ${ }^{2}$ \\ ${ }^{1}$ College of Agriculture, Dharwad, Karnataka, India \\ ${ }^{2}$ College of Agriculture, Vijayapura, University of Agricultural Sciences, \\ Dharwad-580 005, Karnataka, India \\ *Corresponding author
}

\section{A B S T R A C T}

\begin{tabular}{l} 
K e y w o r d s \\
$\begin{array}{l}\text { Alternate crops, } \\
\text { Sugarcane, } \\
\text { Sugarcane } \\
\text { equivalent yield, } \\
\text { Water use } \\
\text { efficiency }\end{array}$ \\
\hline Article Info \\
$\begin{array}{l}\text { Accepted: } \\
10 \text { July } 2020 \\
\text { Available Online: } \\
\text { 10 August } 2020\end{array}$ \\
\hline
\end{tabular}

A field experiment was conducted at Agricultural Research Station, Hukkeri, (Karnataka) to study the efficient alternate crops and cropping systems for sugarcane during 2018-20. There were 11 treatments involving different cropping systems viz., soybean - sorghum ridge gourd $\left(\mathrm{T}_{1}\right)$, pigeon pea + green gram $(1: 1)$ - beans $\left(\mathrm{T}_{2}\right)$, pigeon pea $+\operatorname{soybean}(1: 1)-$ cowpea $\left(\mathrm{T}_{3}\right)$, soybean - wheat - groundnut $\left(\mathrm{T}_{4}\right)$, groundnut - sorghum - sesame $\left(\mathrm{T}_{5}\right)$, maize - cabbage - fallow $\left(\mathrm{T}_{6}\right)$, soybean - wheat - green gram $\left(\mathrm{T}_{7}\right)$, maize - wheat - sesame $\left(\mathrm{T}_{8}\right), \mathrm{Bt}$ cotton - groundnut $\left(\mathrm{T}_{9}\right)$, sugarcane + onion $(1: 2)\left(\mathrm{T}_{10}\right)$ and sugarcane (sole) $\left(\mathrm{T}_{11}\right)$ replicated thrice and laid out in randomized complete block design. The intercropping treatments were in additive series. For comparison between the crop sequences, the yield of all crops in sequences were converted into sugarcane equivalent yield on price basis. Among the cropping systems, maize-cabbage-fallow system recorded significantly higher sugarcane equivalent yield (179.08 t/ha) and total water use efficiency $(199.67 \mathrm{~kg} / \mathrm{ha}-\mathrm{mm})$ compared to rest of the cropping systems. However, sugarcane + onion intercropping recorded significantly higher $(157.91 \mathrm{t} / \mathrm{ha}$ and $125.08 \mathrm{~kg} / \mathrm{ha}-\mathrm{mm}$, respectively) compared to rest of the cropping systems and sugarcane (sole) (111.00 t/ha and $68.64 \mathrm{~kg} / \mathrm{ha}-\mathrm{mm}$, respectively). The cropping systems involving field crops which were significantly higher over sugarcane (sole) are maize-wheat-sesame $(30.65 \mathrm{~kg} / \mathrm{ha}-\mathrm{mm}$ and $117.96 \mathrm{t} / \mathrm{ha}$, respectively), soybean-wheat-groundnut $(27.40 \mathrm{~kg} / \mathrm{ha}-\mathrm{mm}$ and $120.24 \mathrm{t} / \mathrm{h}$, respectively), soybean-wheatgreen gram (23.05 kg/ha-mm and $107.55 \mathrm{t} / \mathrm{ha}$, respectively) and $\mathrm{Bt}$ cotton-groundnut (17.97 kg/ha-mm and $101.71 \mathrm{t} / \mathrm{ha}$, respectively).

\section{Introduction}

Sugarcane is an important commercial crop in India and holds a prominent position as a cash crop. India is having the second largest area and production of sugarcane next to Brazil in the world. In the world, sugarcane area is $26.54 \mathrm{~m}$ ha with production of $1861 \mathrm{~m} \mathrm{t}$ and productivity of $70.13 \mathrm{t} \mathrm{ha}^{-1}$. In India, the area is $4.44 \mathrm{~m}$ ha with production of $306.07 \mathrm{~m} \mathrm{t}$ and productivity of $69.11 \mathrm{t} \mathrm{ha}{ }^{-1}$. Uttar Pradesh, Maharashtra, Karnataka, Tamil Nadu, Bihar, Gujarat, Haryana, Punjab and Andhra Pradesh are the leading states for sugarcane production in India. In Karnataka, sugarcane is cultivated in an area of 0.40 lakh 
ha with production of $27.38 \mathrm{~m} \mathrm{t}$ and productivity of $68.96 \mathrm{t} \mathrm{ha}^{-1}$ (Anon., 2019).

Sugarcane monocropping and sugarcane fallow are the most predominant systems practiced in command areas of Karnataka. These systems for long periods with indiscriminate use of fertilizers and unscientific irrigation management have led to many problems viz., soil salinity, water logging, dominance of pest and diseases incidence and increasing cost of cultivation year by year.

These factors further owe to loss of soil fertility and decline in farm productivity and crop yields in most of the command areas. Successive droughts due to aberrant weather conditions, depleting water resources, higher amount of water requirement by sugarcane compared to other crops, delay in payments by factories are other problems faced every year by farmers and they feel that there is need for the development of an alternate crops and cropping systems for sugarcane in the command area.

The productivity of sugarcane has gone down due to continuous cropping of cereal after cereal being responsible for the deterioration of soil fertility. This clearly indicates that there is an urgent need for crop diversification and integrating cereals, pulses, millets, oilseeds, fibre crops and vegetables which can arrest the declining trend in productivity of cereal-cereal system.

Inclusion of these crop groups in intensive cereal based system itself is a component of integrated plant nutrient supply system. Therefore, efforts were made to promote diversification/alternate cropping systems for sugarcane in command areas integrating different crops for sustaining the productivity and famers' income throughout the year.

\section{Materials and Methods}

The experiment was conducted during 201819 and 2019-20 at Agricultural Research Station, Hukkeri which is situated in the Northern transition zone (Zone 8) of Karnataka. The experimental site was medium black clay loam soil having normal $\mathrm{pH}$ of 7.81 and EC of $0.72 \mathrm{dSm}^{-1}$, medium in organic carbon $(0.53 \%)$, low in available nitrogen $\left(236.74 \mathrm{~kg} \mathrm{ha}^{-1}\right)$, medium in available phosphorus (14.79 $\mathrm{kg} \mathrm{ha}^{-1}$ ) and high in available potassium $\left(317.41 \mathrm{~kg} \mathrm{ha}^{-1}\right)$. It was laid out in Randomised Complete Block Design and replicated thrice. There were 11 treatments consisting of soybean - sorghum ridge gourd $\left(T_{1}\right)$, pigeon pea + green gram $(1: 1)$ - beans $\left(\mathrm{T}_{2}\right)$, pigeon pea + soybean $(1: 1)$ - cowpea $\left(\mathrm{T}_{3}\right)$, soybean - wheat - groundnut $\left(\mathrm{T}_{4}\right)$, groundnut - sorghum - sesame $\left(\mathrm{T}_{5}\right)$, maize - cabbage - fallow $\left(\mathrm{T}_{6}\right)$, soybean wheat - green gram $\left(\mathrm{T}_{7}\right)$, maize - wheat sesame $\left(\mathrm{T}_{8}\right)$, Bt cotton - groundnut $\left(\mathrm{T}_{9}\right)$, sugarcane + onion $(1: 2)\left(\mathrm{T}_{10}\right)$ and sugarcane (sole) $\left(\mathrm{T}_{11}\right)$. The intercropping treatments were in additive series. The seed rate, row spacing and other inputs for kharif, rabi and summer crops was followed as per the recommended package of practices (RPP) and sown the different crops at respective seasons during both the years. Irrigation was provided regularly for sugarcane and to summer season crops and protective irrigation for rabi crops at critical stages. Plant protection and weed management measures were attended and when required. Harvesting was done based on the maturity of individual crops and their respective seasons.

\section{Results and Discussion}

\section{Productivity}

The pooled data of two seasons for kharif resulted in maize recording significantly higher grain yield $\left(\mathrm{T}_{6}, 6123 \mathrm{~kg} / \mathrm{ha}\right)$ which was 
on par with maize $\left(\mathrm{T}_{8}, 6012 \mathrm{~kg} / \mathrm{ha}\right)$ compared to rest of the crops. The other higher yielding crops were viz., groundnut with higher dry pod yield $\left(\mathrm{T}_{5}, 2355 \mathrm{~kg} / \mathrm{ha}\right)$ followed by soybean $\left(\mathrm{T}_{4}, 2275 \mathrm{~kg} / \mathrm{ha}\right)$, soybean $\left(\mathrm{T}_{7}, 2267\right.$ $\mathrm{kg} / \mathrm{ha}), \mathrm{Bt}$ cotton $\left(\mathrm{T}_{9}, 2201 \mathrm{~kg} / \mathrm{ha}\right)$ and soybean $\left(\mathrm{T}_{1}, 2182 \mathrm{~kg} / \mathrm{ha}\right)$ (Table 1$)$.

The pooled data for rabi season showed that, cabbage recorded significantly higher head yield $\left(\mathrm{T}_{6}, 52111 \mathrm{~kg} / \mathrm{ha}\right)$ compared to rest of the crops. Amongst other treatments viz., onion intercropped with sugarcane recorded significantly higher bulb yield $\left(\mathrm{T}_{10}, 4626\right.$ $\mathrm{kg} / \mathrm{ha})$ followed by wheat $\left(\mathrm{T}_{7}, 3206 \mathrm{~kg} / \mathrm{ha}\right)$, wheat $\left(\mathrm{T}_{4}, 3111 \mathrm{~kg} / \mathrm{ha}\right)$, wheat $\left(\mathrm{T}_{8}, 2948\right.$ $\mathrm{kg} / \mathrm{ha}$ ) and sorghum.

During summer (pooled), sugarcane in intercropping system recorded significantly higher cane yield $\left(\mathrm{T}_{10}, 113515 \mathrm{~kg} / \mathrm{ha}\right)$ and it was on par with sugarcane (sole) $\left(\mathrm{T}_{10}, 111008\right.$ $\mathrm{kg} / \mathrm{ha}$ ) compared to other treatments. Next in the order, were ridge gourd with higher fruit yield $\left(\mathrm{T}_{1}, 6864 \mathrm{~kg} / \mathrm{ha}\right)$ followed by beans $\left(\mathrm{T}_{2}\right.$, $6117 \mathrm{~kg} / \mathrm{ha})$, groundnut ( $\left.\mathrm{T}_{9}, 2302 \mathrm{~kg} / \mathrm{ha}\right)$, groundnut $\left(\mathrm{T}_{4}, 2216 \mathrm{~kg} / \mathrm{ha}\right)$, cowpea $\left(\mathrm{T}_{3}, 1355\right.$ $\mathrm{kg} / \mathrm{ha})$ and green gram $\left(\mathrm{T}_{7}, 951 \mathrm{~kg} / \mathrm{ha}\right)$. Sesame recorded the significantly lower seed yield $\left(\mathrm{T}_{5}, 688 \mathrm{~kg} / \mathrm{ha}\right.$ and $\left.\mathrm{T}_{8}, 673 \mathrm{~kg} / \mathrm{ha}\right)$.

Higher productivity of respective crops was due to genetic characteristics of individual crops viz., faster growth (cereals), slow growth (pulses), nutrient uptake of individual crops, nutrient exhaustiveness (cereals), yield potentiality, different ideotypes, early maturity/duration with high yielding ability, photosynthesis and translocation of photosynthates to reproductive organs i.e., from source of sink.

These results are in conformity with the findings of Rao and Rogers (2006), Mukherjee (2010) in rice-cauliflower, Ashutosh et al., (2018) in pigeon pea intercropped with black gram, Bhargavi and Behera (2019) in bottle gourd-onion, Bhadre et al., (2019) in soybean, Bhat et al., (2013) in maize, Biswas (2017) in jute-potato-rice and Sujatha and Babalad (2018) in pigeon pea in intercropping system.

\section{Sugarcane equivalent yield}

During 2018 among the cropping systems, maize-cabbage fallow system recorded significantly higher total sugarcane equivalent yield ( $\mathrm{SEY})\left(\mathrm{T}_{6}, 186.94 \mathrm{t} / \mathrm{ha}\right)$ compared to rest of the cropping systems. However, sugarcane + onion system recorded significantly higher total SEY $\left(\mathrm{T}_{10}, 165.17 \mathrm{t} / \mathrm{ha}\right)$ compared to rest of the cropping systems and sugarcane (sole) $\left(\mathrm{T}_{11}, 117.11 \mathrm{t} / \mathrm{ha}\right)$. The sugarcane (sole) was on par with rest of the treatments except pigeon pea + soybean -cowpea system $\left(\mathrm{T}_{3}\right.$, 89.66 t/ha) (Table 2).

The on par treatments in the order were maize-wheat-sesame $\left(\mathrm{T}_{8}, 136.65 \mathrm{t} / \mathrm{ha}\right)$, soybean-wheat-groundnut $\left(\mathrm{T}_{4}, 130.80 \mathrm{t} / \mathrm{ha}\right)$, soybean-wheat-green gram $\left(\mathrm{T}_{7}, 119.24 \mathrm{t} / \mathrm{ha}\right)$, and Bt cotton-groundnut (113.64 t/ha).

During 2019, because of lower yields due to heavy rain during in June-August months and variation in market price for different crops, the trend was slightly different. Among the cropping systems, significantly higher total SEY was recorded with maize-cabbagefallow system $\left(\mathrm{T}_{6}, 171.23 \mathrm{t} / \mathrm{ha}\right)$ compared to rest of the cropping systems. However, significantly higher total SEY was recorded with sugarcane + onion system $\left(\mathrm{T}_{11}, 150.65\right.$ $\mathrm{t} / \mathrm{ha}$ ) compared to rest of the cropping systems and sugarcane (sole) $\left(\mathrm{T}_{10}, 104.90 \mathrm{t} / \mathrm{ha}\right)$. The sugarcane (sole) was on par with cropping systems viz., soybean-wheat-groundnut $\left(\mathrm{T}_{4}\right.$, $109.67 \mathrm{t} / \mathrm{ha})$, pigeon pea + green gram-beans $\left(\mathrm{T}_{2}, 100.10 \mathrm{t} / \mathrm{ha}\right)$, maize-wheat-sesame $\left(\mathrm{T}_{8}\right.$, $99.26 \mathrm{t} / \mathrm{ha}$ ) and soybean-wheat-green gram $\left(\mathrm{T}_{7}, 95.87 \mathrm{t} / \mathrm{ha}\right)$. 
Table.1 Productivity of alternate crops and cropping systems for sugarcane

\begin{tabular}{|c|c|c|c|}
\hline \multirow[t]{2}{*}{ Treatment } & \multicolumn{3}{|c|}{ Productivity $\left(\mathrm{kg} \mathrm{ha}^{-1}\right)$} \\
\hline & Kharif & Rabi & Summer \\
\hline $\mathrm{T}_{1}$ : Soybean - sorghum - ridge gourd & 2182 & 1676 & 6864 \\
\hline$T_{2}:$ Pigeon pea + green gram* $(1: 1)$ - beans & 596 & 1460 & 6117 \\
\hline$T_{3}:$ Pigeon pea + soybean* $(1: 1)$ - cowpea & 698 & 1512 & 1355 \\
\hline$T_{4}:$ Soybean - wheat - groundnut & 2275 & 3111 & 2216 \\
\hline$T_{5}:$ Groundnut - sorghum - sesame & 2355 & 1799 & 688 \\
\hline$T_{6}:$ Maize - cabbage - fallow & 6123 & 52111 & $-\cdots$ \\
\hline$T_{7}:$ Soybean - wheat - green gram & 2267 & 3206 & 951 \\
\hline $\mathbf{T}_{8}:$ Maize - wheat - sesame & 6012 & 2948 & 673 \\
\hline$T_{9}:$ Bt cotton - groundnut & \multicolumn{2}{|l|}{2201} & 2302 \\
\hline$T_{10}:$ Sugarcane + onion* $(1: 2)$ & & 4626 & 113515 \\
\hline $\mathbf{T}_{11}:$ Sugarcane (sole) & & & 111008 \\
\hline S.Em. \pm & 151.95 & 228.53 & 1316.40 \\
\hline $\operatorname{LSD}(\mathbf{p}=\mathbf{0 . 0 5})$ & 455.54 & 685.14 & 3911.23 \\
\hline
\end{tabular}

Note: Bt cotton, pigeon pea and sugarcane are considered as kharif, rabi and summer crops, respectively,

*Additive series intercropping systems

Table.2 Sugarcane equivalent yield (SEY) of alternate crops and cropping systems

\begin{tabular}{|c|c|c|c|}
\hline \multirow[t]{2}{*}{ Treatment } & \multicolumn{3}{|c|}{ Sugarcane equivalent yield $\left(\mathrm{t} \mathrm{ha}^{-1}\right)$} \\
\hline & 2018 & 2019 & Pooled \\
\hline$T_{1}$ : Soybean - sorghum - ridge gourd & 116.78 & 89.37 & 103.08 \\
\hline$T_{2}:$ Pigeon pea + green gram* $(1: 1)$ - beans & 116.22 & 100.10 & 108.17 \\
\hline$T_{3}:$ Pigeon pea + soybean $^{*}(1: 1)-$ cowpea & 89.66 & 72.45 & 81.05 \\
\hline$T_{4}$ : Soybean - wheat - groundnut & 130.80 & 109.67 & 120.24 \\
\hline$T_{5}:$ Groundnut - sorghum - sesame & 115.38 & 92.03 & 103.70 \\
\hline$T_{6}$ : Maize - cabbage - fallow & 186.94 & 171.23 & 179.08 \\
\hline$T_{7}:$ Soybean - wheat - green gram & 119.24 & 95.87 & 107.55 \\
\hline$T_{8}$ : Maize - wheat - sesame & 136.65 & 99.26 & 117.96 \\
\hline$T_{9}:$ Bt cotton - groundnut & 113.64 & 89.79 & 101.71 \\
\hline $\mathbf{T}_{10}:$ Sugarcane + onion* $(1: 2)$ & 165.17 & 150.65 & 157.91 \\
\hline $\mathbf{T}_{11}$ : Sugarcane (sole) & 117.11 & 104.91 & 111.00 \\
\hline S.Em. \pm & 5.43 & 3.51 & 3.72 \\
\hline $\operatorname{LSD}(\mathbf{p}=\mathbf{0 . 0 5})$ & 16.35 & 10.35 & 10.98 \\
\hline
\end{tabular}

*Additive series intercropping systems 
Table.3 Water use efficiency of alternate crops and cropping systems for sugarcane

\begin{tabular}{|c|c|c|c|c|}
\hline \multirow[t]{2}{*}{ Treatment } & \multicolumn{4}{|c|}{ Water use efficiency $\left(\mathrm{kg} \mathrm{ha}^{-1}-\mathrm{mm}\right)$} \\
\hline & Kharif & Rabi & Summer & Total \\
\hline$T_{1}$ : Soybean - sorghum - ridge gourd & 7.25 & 14.51 & 34.88 & 56.64 \\
\hline$T_{2}:$ Pigeon pea + green gram $^{*}(1: 1)-$ beans & \multicolumn{2}{|c|}{8.20} & 21.69 & 29.89 \\
\hline$T_{3}:$ Pigeon pea + soybean $^{*}(1: 1)$ - cowpea & \multicolumn{2}{|c|}{7.00} & 5.25 & 12.25 \\
\hline$T_{4}:$ Soybean - wheat - groundnut & 7.55 & 8.51 & 11.34 & 27.40 \\
\hline$T_{5}:$ Groundnut - sorghum - sesame & 7.68 & 15.59 & 3.79 & 27.06 \\
\hline$T_{6}:$ Maize - cabbage - fallow & 19.23 & 180.44 & --- & 199.67 \\
\hline$T_{7}$ : Soybean - wheat - green gram & 7.53 & 8.77 & 6.75 & 23.05 \\
\hline$T_{8}:$ Maize - wheat - sesame & 18.88 & 8.06 & 3.71 & 30.65 \\
\hline $\mathbf{T}_{9}:$ Bt cotton - groundnut & \multicolumn{2}{|l|}{6.19} & 11.78 & 17.97 \\
\hline $\mathrm{T}_{10}$ : Sugarcane + onion ${ }^{*}(1: 2)$ & \multicolumn{3}{|r|}{125.08} & 125.08 \\
\hline$T_{11}:$ Sugarcane (sole) & \multicolumn{3}{|r|}{68.64} & 68.64 \\
\hline S.Em. \pm & 0.51 & 1.01 & 1.11 & 1.42 \\
\hline $\operatorname{LSD}(p=0.05)$ & 1.53 & 3.07 & 3.30 & 4.19 \\
\hline
\end{tabular}

Note: For $T_{2}, T_{3}$ and $T_{10}$, quantity of water applied only to the base crop/main crop and base crop equivalent yield of intercrop was considered for calculation of WUE of intercropping system.

*Additive series of intercropping systems

For pooled results, maize-cabbage-fallow system recorded significantly higher total SEY $\left(\mathrm{T}_{6}, 179.08 \mathrm{t} / \mathrm{ha}\right)$ compared to rest of the cropping systems. However, the sugarcane + onion intercropping system recorded significantly higher total SEY $\left(\mathrm{T}_{10}, 157.91\right.$ t/ha) compared to rest of the cropping systems and sugarcane (sole) $\left(\mathrm{T}_{11}, 111.00 \mathrm{t} / \mathrm{ha}\right)$. The sugarcane (sole) was on par with soybeanwheat-groundnut $\left(\mathrm{T}_{4}, 120.24 \mathrm{t} / \mathrm{ha}\right)$, maizewheat-sesame $\left(\mathrm{T}_{8}, 117.96 \mathrm{t} / \mathrm{ha}\right)$, pigeon pea + green gram-beans $\left(\mathrm{T}_{2}, 108.17 \mathrm{t} / \mathrm{ha}\right)$, soybeanwheat-green gram $\left(\mathrm{T}_{7}, 107.55 \mathrm{t} / \mathrm{ha}\right)$, groundnut-sorghum-sesame $\left(\mathrm{T}_{5}, 103.70 \mathrm{t} / \mathrm{ha}\right)$, soybean-sorghum-ridge gourd $\left(\mathrm{T}_{1}, 103.08\right.$ $\mathrm{t} / \mathrm{ha})$ and $\mathrm{Bt}$ cotton-groundnut $\left(\mathrm{T}_{9}, 101.71\right.$ t/ha). However, pigeon pea +soybean-cowpea system recorded significantly lower total SEY $\left(\mathrm{T}_{3}, 81.05 \mathrm{t} / \mathrm{ha}\right)$. This was due to high yielding potentiality of these crops and prevailing higher market price of the produce and also residual advantages of legume crops to the succeeding crops. Mishra et al., (2007) also observed higher productivity with inclusion of vegetables in rice-based cropping systems.
These results are also in line with the findings of Bhargavi and Behera (2019) in bottle gourd-onion, Ashutosh et al., (2018) in pigeon pea intercropped with black gram, Mukherje (2010 and 2016) in rice-mung and Gangwar and Singh (2011) in different alternative cropping systems.

\section{Water use efficiency}

During kharif season, among the crops, higher WUE was recorded with maize $\left(\mathrm{T}_{6}, 19.23\right.$ $\mathrm{kg} / \mathrm{ha}-\mathrm{mm})$ and it was on par with maize $\left(\mathrm{T}_{8}\right.$, $18.88 \mathrm{~kg} / \mathrm{ha}-\mathrm{mm})$. The next best WUE was with groundnut $\left(\mathrm{T}_{5}, 7.68 \mathrm{~kg} / \mathrm{ha}-\mathrm{mm}\right)$, soybean $\left(\mathrm{T}_{4}, 7.55 \mathrm{~kg} / \mathrm{ha}-\mathrm{mm}\right)$, soybean $\left(\mathrm{T}_{7}, 7.53 \mathrm{~kg} / \mathrm{ha}-\right.$ $\mathrm{mm})$ and soybean $\left(\mathrm{T}_{1}, 7.25 \mathrm{~kg} / \mathrm{ha}-\mathrm{mm}\right)$. The significantly lower WUE was noticed with Bt cotton $\left(\mathrm{T}_{9}, 6.19 \mathrm{~kg} / \mathrm{ha}-\mathrm{mm}\right)$ (Table 3$)$.

During rabi, among the individual crops, cabbage recorded significantly higher WUE ( $\left.\mathrm{T}_{6}, 180.44 \mathrm{~kg} / \mathrm{ha}-\mathrm{mm}\right)$ compared to rest of the crops. Next in the order were with sorghum $\left(\mathrm{T}_{5}, 15.59 \mathrm{~kg} / \mathrm{ha}-\mathrm{mm}\right)$, sorghum $\left(\mathrm{T}_{1}\right.$, 
$14.51 \mathrm{~kg} / \mathrm{ha}-\mathrm{mm})$, wheat $\left(\mathrm{T}_{7}, 8.77 \mathrm{~kg} / \mathrm{ha}-\mathrm{mm}\right)$, wheat $\left(\mathrm{T}_{4}, 8.51 \mathrm{~kg} / \mathrm{ha}-\mathrm{mm}\right)$, pigeon pea $\left(\mathrm{T}_{2}\right.$, $8.20 \mathrm{~kg} / \mathrm{ha}-\mathrm{mm})$ and wheat $\left(\mathrm{T}_{8}, 8.06 \mathrm{~kg} / \mathrm{ha}-\right.$ $\mathrm{mm})$. The significantly lower WUE was noticed with pigeon pea $\left(\mathrm{T}_{3}, 7.00 \mathrm{~kg} / \mathrm{ha}-\mathrm{mm}\right)$

Among the individual crops, during summer season, sugarcane intercropped with onion recorded significantly higher WUE $\left(\mathrm{T}_{10}\right.$, $125.08 \mathrm{~kg} / \mathrm{ha}-\mathrm{mm}$ ) compared to rest of the crops. It was followed by sugarcane (sole) $\left(\mathrm{T}_{11}, 68.64 \mathrm{~kg} / \mathrm{ha}-\mathrm{mm}\right)$, ridge gourd $\left(\mathrm{T}_{1}, 34.88\right.$ $\mathrm{kg} / \mathrm{ha}-\mathrm{mm})$, beans $\left(\mathrm{T}_{2}, 21.69 \mathrm{~kg} / \mathrm{ha}-\mathrm{mm}\right)$, groundnut $\left(\mathrm{T}_{9}, 11.78 \mathrm{~kg} / \mathrm{ha}-\mathrm{mm}\right)$ groundnut $\left(\mathrm{T}_{4}, 11.34 \mathrm{~kg} / \mathrm{ha}-\mathrm{mm}\right)$, green gram $\left(\mathrm{T}_{7}, 6.75\right.$ $\mathrm{kg} / \mathrm{ha}-\mathrm{mm})$, cowpea $\left(\mathrm{T}_{3}, 5.25 \mathrm{~kg} / \mathrm{ha}-\mathrm{mm}\right)$ and sesame $\left(\mathrm{T}_{5}, 3.79 \mathrm{~kg} / \mathrm{ha}-\mathrm{mm}\right)$. Significantly lower WUE was noticed with sesame $\left(\mathrm{T}_{8}\right.$, $3.71 \mathrm{~kg} / \mathrm{ha}-\mathrm{mm}$ ).

The significantly higher total water use efficiency (WUE) was with maize-cabbagefallow system ( $\left.\mathrm{T}_{6}, 199.67 \mathrm{~kg} / \mathrm{ha}-\mathrm{mm}\right)$ compared to rest of the cropping systems This was because of higher sugarcane equivalent yield, application of individual water requirement of crops and other inputs in the cropping system. A proper water supply and nitrogen application rate are also major contributors to higher economic yield and water use efficiency (Fan et al., 2001 and Zhang et al., 1998).

However, the sugarcane + onion system recorded significantly higher total WUE $\left(\mathrm{T}_{10}\right.$, $125.08 \mathrm{~kg} / \mathrm{ha}-\mathrm{mm}$ ) compared to rest of the cropping systems and sugarcane (sole) $\left(\mathrm{T}_{11}\right.$, $68.64 \mathrm{~kg} / \mathrm{ha}-\mathrm{mm}$ ). The sugarcane (sole) was significantly higher over rest of the cropping systems. The next best cropping systems with higher WUE were soybean-sorghum-ridge gourd $\left(\mathrm{T}_{1}, 56.64 \mathrm{~kg} / \mathrm{ha}-\mathrm{mm}\right)$ followed by maize-wheat-sesame $\left(\mathrm{T}_{8}, 30.65 \mathrm{~kg} / \mathrm{ha}-\mathrm{mm}\right)$, pigeon pea + green gram-beans $\left(\mathrm{T}_{2}, 29.89\right.$ $\mathrm{kg} / \mathrm{ha}-\mathrm{mm})$, soybean-wheat-groundnut $\left(\mathrm{T}_{4}\right.$, $27.40 \mathrm{~kg} / \mathrm{ha}-\mathrm{mm})$, groundnut-sorghum- sesame $\left(\mathrm{T}_{5}, 27.06 \mathrm{~kg} / \mathrm{ha}-\mathrm{mm}\right)$, soybeanwheat-green gram $\left(\mathrm{T}_{7}, 23.05 \mathrm{~kg} / \mathrm{ha}-\mathrm{mm}\right)$ and Bt cotton-groundnut ( $\left.\mathrm{T}_{9}, 17.97 \mathrm{~kg} / \mathrm{ha}-\mathrm{mm}\right)$. The total WUE was significantly lower with pigeon pea + soybean-cowpea $\left(\mathrm{T}_{3}, 12.25\right.$ $\mathrm{kg} / \mathrm{ha}-\mathrm{mm})$. This was due to the lower SEY, individual crop yielding ability and relationship between economic yield and nutrient application and requirement of water based on the need of individual crops.

It can be concluded that, considering field crop + vegetable alternate cropping system for sugarcane, maize-cabbage fallow system recorded significantly higher sugarcane equivalent yield (179.08 t/ha) and total water use efficiency (199.67 kg/ha-mm) compared to rest of the cropping systems. Sugarcane + onion intercropping was significantly higher recorded $(157.91 \mathrm{t} / \mathrm{ha}$ and $125.08 \mathrm{~kg} / \mathrm{ha}-\mathrm{mm}$, respectively) compared to rest of the cropping systems. Based on alternate cropping systems involving field crops only, maize-wheatsesame (117.96 t/ha and $30.65 \mathrm{~kg} / \mathrm{ha}-\mathrm{mm}$, respectively), soybean-wheat-groundnut (and $120.24 \mathrm{t} / \mathrm{h}$ and $27.40 \mathrm{~kg} / \mathrm{ha}-\mathrm{mm}$, respectively), soybean-wheat-green gram (107.55 t/ha and $23.05 \mathrm{~kg} / \mathrm{ha}-\mathrm{mm}$, respectively) and Bt cottongroundnut $(101.71 \mathrm{t} / \mathrm{ha}$ and $17.97 \mathrm{~kg} / \mathrm{ha}-\mathrm{mm}$, respectively) were significantly higher.

\section{References}

Anonymous, 2019, Agriculture Statistics at a Glance, Ministry of Agriculture and Farmers' Welfare, Government of India, New Delhi.

Ashutosh, B., Singh, V.K., Shambhoo Prasad, Naveen Rawat and Hariom Shah, 2018, Productivity and profitability of pigeon pea (Cajanus cajan) in pigeon pea based cropping system under different integrated nutrient management practices in Tarai region of Uttarakhand. Int. J. Chem. Stud., 6(2):3488-3492. 
Bhadre, C.K., Narkhede, W.N. and Gokhale, D.N., 2019, Growth, yield and economics of soybean-safflower cropping sequence as influenced by different land configuration and nutrient management. J. Pharmacogn. Phytochem., 8(1):169-173.

Bhargavi, B. and Behera, U.K., 2019, System productivity and energetics of high value crops embedded diversified cropping systems, Int. J. Curr. Microbiol. Appl. Sci., 8(1):1895-1905.

Bhat, R. A., Latief Ahmad and Wani, G. A., 2013, Growth, yield and economics of maize as affected by cropping sequences, rates and frequency of farm yard manure (FYM). African J. Agric. Res., 8(27): 3632-3638.

Biswas, B., 2017, Cropping system analysis for agricultural sustainability productivity, economy, ecology and energy use efficiency. J. Exp. Biol. Agric. Sci., 5(3):294-301.

Fan, X., Li, Y.K., Horst, W.J., Schenk, M.K., Burkert, A., Claasen, N., Flessa, H., Frommer, W.B. and Goldbach, H., 2001, Effect of drought stress and drought tolerance heredity on nutrient efficiency on winter wheat. Springer Sci. Rev., 92:62-65.

Gangwar, B. and Singh, A.K., 2011, Efficient alternative cropping systems, Project Directorate for Farming Systems Research, Modipuram, Meerut, India. pp 339.
Mishra, M.M., Nanda, S.S., Mohanty, M., Pradhan, K.C. and Mishra, S.S., 2007, Crop diversification under rice based cropping system in western Orissa. In: Extended Summaries: $3^{\text {rd }}$ National Symposium on Integrated Farming Systems, October 26-28, 2007, Durgapura, Jaipur.

Mukherjee, D., 2010, Productivity, profitability and apparent nutrient balance under different crop sequence in mid hill condition. Indian J. Agric. Sci., 80 (5): 72-74.

Mukherjee, D., 2016,. Evaluation of different crop sequence production potential, economics and nutrient balance under new alluvial situation of NEPZ. Int. J. Horti. Agric., 1(1): 1-5.

Rao, N. H. and Rogers, P. P., 2006, Assessment of agricultural sustainability. Current Sci., 91 (4):439446.

Sujatha, H.T. and Babalad, H.B., 2018, System productivity and economics of transplanted and direct sown pigeon pea at different cropping geometry and intercropping systems. Int. J. Pure App. Biosci., 6 (1): 694-700.

Zhang, J., Sui, X., Li, B., Su, B., Li, J. and Zhou, D., 1998, An improved water use efficiency for winter wheat grown under reduced irrigation. Field Crops Res., 59:91-98.

\section{How to cite this article:}

Sadashivanagowda, S. N. O., S. C. Alagundagi and Nadagouda, B. T. 2020. Efficient Alternate Crops and Cropping Systems for Sugarcane. Int.J.Curr.Microbiol.App.Sci. 9(08): 135-141. doi: https://doi.org/10.20546/ijcmas.2020.908.014 